\title{
Is Ethical Money Sensitive to Past Returns? The Case of Portfolio Constraints and Persistence of Islamic Funds*
}

\author{
Omneya Abdelsalam \\ University of Durham
}

\author{
Meryem Duygun \\ University of Hull
}

\author{
Juan Carlos Matallín \\ Universitat Jaume I
}

\author{
Emili Tortosa-Ausina \\ Universitat Jaume I and Ivie
}

December 4, 2014

\begin{abstract}
We analyze the performance persistence and survivorship bias of Islamic funds. The remarkable growth seen in this type of ethical funds over the last two decades raises the question of how non-financial attributes (such as beliefs and value systems) influence performance and performance persistence. We propose a refined version of the procedures used in the literature based on a cross-sectional test to control for the significance of the recursive portfolios according to past performance. This procedure allows us to correctly identify whether this abnormal performance is due to a dynamic investment strategy based on past performance, or whether it is obtained by simply investing in a particular set of mutual funds. The analysis shows that Islamic funds were particularly resilient during the 2007-2008 financial crisis. Regarding persistence, its significance varies depending on the time horizon (yearly/half-yearly), survivorship, or tail of the distribution. In particular, we find that persistence only exists for the best funds, whereas for the worst funds the results are not significant.
\end{abstract}

Keywords: Islamic funds, SRI funds, performance, persistence

JEL Classification: G2, N25, Z12

Communications to: Meryem Duygun, Business School, Hull University, Room 130 Wharfe Building, Cottingham Road, Hull, North Humberside, HU6 7RX, UK. Tel.: +44 (0) 1482463244, e-mail: M.Duygun@hull.ac.uk

\footnotetext{
${ }^{*}$ We thank an anonymous referee and the associate editor, Sanjiv Das, whose comments helped greatly to the overall improvement of the article, as well as those by Mohamed Shaban on a preliminary version. Juan Carlos Matallín and Emili Tortosa-Ausina acknowledge the financial support provided by Ministerio de Ciencia e Innovación (ECO2011-27227/ECON), Universitat Jaume I (P1.1B2012-07 and P1.1B2014-17) and Generalitat Valenciana (PROMETEOII/2014/046 and ACOMP/2014/283). All authors are grateful to El Shaarani Centre for Islamic Business and Finance at Aston Business School for financially supporting this project.
} 


\section{Introduction}

A large amount of the literature on financial economics has dealt with understanding the performance of mutual funds, given their large impact on wealth. Consequently, they have a strong relevance for investors, managers and academics alike. Both individual and institutional investors have an interest in the performance persistence of funds. In particular, they are focused on performance measuring methods which can guide funds to the best future results. Thus, most individual investors and their advisors spend a large amount of time studying the past performance of the funds in which they are considering investing.

Given the current state of the literature is now, one may easily infer that the conclusions as to the existence (or absence) of persistence might bear some degree of heterogeneity. Specifically, much of the literature, that based their tests of persistence on correlation in period-to-period fund performance found that persistence existed over various horizons (at least one year). Some studies (Hendricks et al., 1993; Goetzmann and Ibbotson, 1994; Brown and Goetzmann, 1995) attributed short-term persistence (up to three years) to strategies based on common investment or "hot hands", whereas others (Grinblatt and Titman, 1992; Elton et al., 1993, 1996) found it over longer time horizons (five to ten years) and attributed it to managerial stock-picking skills.

These results were partly explained in an influential paper written by Carhart (1997), who found that persistence was due to an omitted factor explaining equity returns, namely, the "momentum effect", rather than managers' skills (Jegadeesh and Titman, 1993) - with the exception of the continuously underperforming of the worst performing funds. However, as indicated by Busse et al. (2010), in some studies it has been found that, when controlling for momentum, performance is predictable (Bollen and Busse, 2005a; Cohen et al., 2005; Avramov and Wermers, 2006; Kosowski et al., 2006), whereas in others little to no evidence of persistence or skill was found (Barras et al., 2009; Fama and French, 2010).

However, the literature has evolved and recent contributions have failed to agree on the existence (or lack) of persistence, along with likely explanations. For instance, Quigley and Sinquefield (2000), Cuthbertson et al. (2008) and Massa and Patgiri (2009) have come to similar conclusions to Carhart (1997) - i.e. no significant evidence of persistence in the analysis of investment strategies based on past performance. In other studies, such as Lynch and Musto (2003), Cohen et al. (2005) and Kosowski et al. (2006), the results have found persistence among winners, but not among losers. Similar results have been found by Wermers (2003) who, by examining managers' momentum, found evidence of persistence in superior growth funds, whereas in the case of Kosowski et al. (2006), whereby using net returns after trading costs and fees, persistence is obtained for growth-oriented funds, with no evidence for managerial skills for income-oriented funds.

A particular branch of literature which focuses on the performance of mutual funds has, over the last several decades, taken an interest in analysing morally/ethically-oriented funds. Socially Responsible Funds (SRI) and Islamic Funds are examples of ethical funds which, when evaluating their investments, ensure that their portfolios are aligned with their beliefs and value systems (Sauer, 1997; Godlewski 
et al., 2013). These funds apply both moral/social and financial criteria, in screening their investments. As various ethical funds display distinctive styles of investment (Bauer et al., 2005), applying different screening criteria (Derigs and Marzban, 2008), both the performance and the performance persistence of these different types of ethical funds (SRI and Islamic) are likely to be influenced by the various constraints applied.

In the particular case of Islamic funds, on which we focus, a handful of studies compared the performance of these funds with their conventional counterparts (Ahmad and Ibrahim, 2002; Girard and Hassan, 2008; Hashim, 2008; Albaity and Ahmad, 2008; BinMahfouz and Hassan, 2012; Dharani and Natarajan, 2011; Mansor and Bhatti, 2011). However, the empirical evidence available on Islamic funds is much scarcer in comparison to the literature focusing on SRI funds. In this regard, several studies concluded that there was no particular difference to be found in the way in which restricted Islamic funds performed vis-à-vis their conventional counterparts. Nevertheless, an accurate analysis of this relationship might be intricate. For instance, in their study Abdelsalam et al. (2014b) found that depending on the quantile of the conditional distribution of performance considered, SRI or Islamic funds were on top. Alam et al. (2013) analyzed the performance over two consecutive periods and found a positive persistence but it was weak and not statistically significant. However, literature focusing explicitly on the persistence of Islamic mutual funds is almost entirely non-existent, and few existing contributions can be found (Alam et al., 2013; Abdelsalam et al., 2014a). The current study, by analysing the performance persistence for a particular type of ethical funds, contributes to fill this gap in the literature where research is either scarce or absent.

Islamic mutual funds have very particular screening features such as, for instance, investing in Shari'ah-compliant assets. ${ }^{1}$ Islamic funds extend financial filters on the selected equity, which would result in a further-restricted universe-according to the percentage of interest paid or received and leverage. However, in terms of other relevant traits, they bear some of the same attributes as SRI funds. The similarity is based on investing in a restricted universe of assets after applying their screening criteria. Consequently, according to Askari et al. (2010), in the case of restricted funds, when compared with their conventional counterparts, their constituents are likely to experience greater stability. This leads to an expectation that there may be a payoff in terms of higher persistence for these types of funds.

In this context, the aims of this study are twofold. The first aim, of a more applied nature, is to analyse the performance persistence of a large and updated sample of Islamic funds for which, as stated above, despite their relevance, the empirical evidence on them is virtually non-existent. The second aim is more methodological, testing for persistence using a recursive portfolio approach, for which performance investment strategies are based on past performance which has been previously considered in the literature on mutual fund performance persistence (see Carhart, 1997; Grinblatt and Titman, 1993; Fama and French, 2010). This recursive portfolio approach is implemented by means of two algorithms.

\footnotetext{
${ }^{1}$ Shari'ah-compliant assets avoid Shari'ah prohibited companies such as those dealing with alcohol, tobacco, arms, biotechnology for human cloning, and companies with heavy debt financing to avoid dealing with interest.
} 
The first one has been widely applied in the literature. The second one is more innovative, as it is a procedure which enables distinguishing whether the abnormal performance results from a dynamic investment strategy based on past performance, or whether it is obtained by simply investing in a particular set of mutual funds. Therefore, we generate synthetic portfolios whose abnormal performance is used to test for the cross-sectional significance of the recursive portfolios investing according to past performance. In a case where persistence existed, a recursive portfolio investing in the worst (best) funds would show a negative (positive) abnormal performance differing significantly from that obtained by following a random strategy-i.e. investing in the mutual funds without any particular criteria.

Our results on persistence have been explored from a multiplicity of angles. Although, in general, they show that persistence exists, this is only significant for the best funds. Results also vary when controlling for the time window (evidence of persistence is stronger under short-term horizons), and when performing a separate analysis for survivors and non-survivors (the evidence is slightly worse when only the former are considered), a result which partly corroborates previous findings for conventional funds (Carhart et al., 2002). Our results for Islamic funds differ from previous results for SRI funds suggesting that, although they are sometimes included under the same category of "ethical" funds (Renneboog et al., 2011), there are actually performance differences between these classes of ethical funds.

The remainder of the paper is structured as follows: Section 2 briefly outlines some of the most important characteristics of Islamic funds. Section 3 provides details on the methodologies used to measure funds' performance and persistence. Section 4 describes the data used in the study, whereas Section 5 presents the results. Finally, Section 6 presents some concluding remarks.

\section{Some background on Islamic funds}

Over the last twenty years certain types of mutual funds have grown in leaps and bounds. This refers, inter alia, to faith-based mutual funds (such as Islamic funds), and SRI (or socially responsible investments). The speed of growth of these two fund types has exceeded their conventional counterparts. This could be due to recent reports of accounting and environmental scandals highlighted in business ethics literature (Bauer et al., 2007). Techniques which combine the financial goals of the investors with their commitment to moral or social concerns, or both, are used by both Islamic funds and SRI (Hiagh and Hazelton, 2004).

SRI emerged in response to the views of religious groups who condemned investment in certain stocks deemed "sin" reserves. Later, SRI slowly developed as a concept, being enhanced and expanded by projects related to human rights, ecology and an anti-war stance. No altogether recognized definitions prevail for ESG, or Environmental, Social, and Governance principles; or for SRI, or Socially Responsible Investment. Islamic equity investment started to gain relevance in 1994. In that year, under a new religious prescription (Hayat and Kraeussl, 2011), Muslim investors, subject to strict guidelines, were allowed to trade in international stocks. Thereafter, Islamic investment has rapidly increased. 
Investors from across the world began to subscribe the Islamic investment market and, by the end of the 2000s, Dow Jones, MSCI and FTSE were offering hundreds of Islamic equity indices-according to Ernst \& Young (2011), over 800.

There are five pillars involved in Islamic finance. Four of these pillars refer to prohibitions: investment in banned activities; Riba, or usury; Gharar, or excessive uncertainty; and Maysir, or speculation. The final pillar has to do with the promotion of the sharing of risks and returns (Shanmugam and Zahari, 2009; Hayat and Kraeussl, 2011). The running of Islamic funds is guided by a Shari'ah Supervisory Board (SSB), or a panel of Shari'ah experts, which closely checks the compliance of companies and funds. Owing to the non-existence of a global SSB, each fund appoints its own SSB, which results in the application of varying interpretations of Shari'ah screening criteria.

In addition, Islamic funds reject investments having fixed income; ${ }^{2}$ for example, certain derivatives, such as options, certificates of deposit, preferred stocks, and corporate bonds. They also impose further financial ratio screens on the chosen equity. For instance, the percentage of interest received or paid out and leverage should not exceed a certain threshold set by their SSB. Islamic funds do not normally apply positive filters, which are applied by SRI funds such as human rights; transparency of corporate practice; and best-in-class environmental filters.

\section{Performance and persistence measurement}

\subsection{Performance measurement}

This section briefly describes the models used to measure the performance and performance persistence of Islamic funds. In order to measure performance we use a linear model which adjusts a fund's returns for different risk factors. This approach has been widely used in the literature. In parallel to the development of asset pricing models, taking the study by Jensen (1968) as a starting point, many other studies have considered several factors, such as those proposed by Fama and French (1993) and the momentum factor proposed by Carhart (1997). Furthermore, other studies, such as Sharpe (1992a) and Elton et al. (1993) have also proposed linear models including the returns of the benchmarks represented by the asset classes in which the evaluated funds invest as factors. Since our objective is to evaluate funds with a specific investment strategy and with a broad geographical scope for investment, we considered it to be more appropriate to apply a linear model with multiple benchmarks such as the one in the following expression:

$$
r_{p, t}=\alpha_{p}+\beta_{p, w} r_{w, t}+\beta_{p, i} r_{i, t}+\beta_{p, m} r_{m, t}+\varepsilon_{p, t}
$$

where $r_{p, t}$ is the excess return over the risk-free asset of the assessed fund. The constant in the model,

\footnotetext{
${ }^{2}$ It is considered discriminatory and unfair, by Islamic standards, to charge a fixed rate of interest on an investment loan. This is because the entrepreneur, or borrower, accepts the full risk, while the lender receives the set amount, whether or not the venture is successful. On the other hand, the lender, when the profit is very high, will gain a relatively smaller portion of the profit. The borrower gains the greater portion, which implies that there has been an uneven sharing of both profit and risk (Novethic, 2009).
} 
$\alpha_{p}$, measures the fund's abnormal performance. The risk factors are the excess returns corresponding to: (i) a global benchmark representing investment in different markets around the world, $r_{w, t}$; (ii) a specific benchmark representing investment constrained by Islamic, $r_{i, t}$; and (iii) a specific benchmark for investment in the Middle East or emerging markets given the characteristics of the funds under analysis, $r_{m, t}$.

\subsection{Persistence}

With respect to the main objective of the study, i.e. evaluating the performance persistence of our sample of Islamic funds, we will apply the so-called recursive portfolio approach, initially proposed in the literature by Carhart (1997). The recursive portfolio approach is one of the most commonly used methods in the literature. Several examples would include Bollen and Busse (2005a), Busse et al. (2010), Fama and French (2010) and Kosowski et al. (2006), who have also proposed variations to this approach; in some cases related to the statistical significance of the alphas. According to the recursive portfolio approach, persistence is assessed by analysing the abnormal performance of portfolios that invest according to the mutual funds' past performance in the previous periods. Persistence will be calculated for two types of periodicity, semiannual (half-yearly) and annual. This methodology is in line with the method proposed by Alam et al. (2013). Specifically, these authors analyze the persistence of Islamic and conventional mutual funds by exploring the relationship between the performances estimated in two consecutive periods. Mutual fund persistence should imply a positive relationship, which in our case is also a necessary condition in order for the recursive portfolio, which invests according to past performance, to achieve a positive performance. Moreover, in line with Alam et al. (2013), when estimating performance for a non-overlapping rolling window we also allow the model parameters to be time-variant. This is particularly interesting, given the ample empirical evidence in the literature on time-varying systematic risk.

We propose to apply our recursive portfolio approach by means of the following algorithm (algorithm I):

1. We estimate the performance of the mutual funds by means of Equation (1) for the first period of the sample.

2. We rank mutual funds in increasing order according to the performance they achieved in the period, to form deciles.

3. At the beginning of the next period we form ten equally weighted portfolios according to decile past performance, $D_{1}, \ldots, D_{10}$, where the first portfolio $\left(D_{1}\right)$ invests in the worst performing funds in the previous period and, conversely, the last portfolio $\left(D_{10}\right)$ invests in the previous period's best funds. The same investment strategy is followed for the other deciles.

4. This procedure is repeated at the beginning of each period (i.e., we would restart in step 1), so that each portfolio represents a dynamic investment strategy that rebalances selected funds in 
accordance with their previous performance.

5. We therefore compute the daily return of the ten portfolios and then we estimate the abnormal performance of the portfolio, also using model (1).

We hypothesize that where there is persistence in mutual fund performance, a portfolio with investments based on a poor (good) past performance will show a negative (positive) abnormal performance.

However, it is necessary to correctly identify whether this abnormal performance is due, precisely, to a dynamic investment strategy based on past performance, or whether it is obtained by simply investing in a particular set of mutual funds. Bearing this in mind, we can contribute to the literature by proposing a cross-sectional test to control for significance of the recursive portfolios. Specifically, we would apply another algorithm (algorithm II) in which:

1. In the first period of the sample we randomly rank mutual funds to form deciles.

2. At the beginning of the next period we randomly form ten equally weighted portfolios.

3. This procedure is repeated at the beginning of each period, so that each synthetic portfolio represents a dynamic investment strategy that rebalances selected funds randomly.

4. We then estimate the abnormal performance of these synthetic portfolios using model (1).

5. Thus, for all recursive portfolios, we generate a set with a higher number of synthetic portfolios whose abnormal performances define a cross-sectional distribution with which to test significance.

Therefore, we would generate synthetic portfolios in the same way as recursive portfolios. However, the difference would be that now the dynamic investment strategy would not be based on the mutual funds' past performance, but that the mutual funds invested in would be selected randomly. According to algorithm II, where there is persistence in the added value from managers, a recursive portfolio that invests in the worst (best) mutual funds should show a negative (positive) abnormal performance differing significantly from that obtained by a random strategy that invests in the mutual funds without any particular criteria.

\subsection{Performance persistence: theoretical background}

In this section the aim is to model mutual fund performance persistence according to market environment and manager ability. Previous studies have proposed a theoretical model for explaining funds' performance. In this sense, Grinold (1989) and Grinold and Kahn (2000) share the contention that a fund's performance is directly proportional to two variables: (i) managerial ability and forecasting skills; and (ii) the number of independent forecasts that managers can do in a given time period. Defining performance measurement as the comparison of funds' returns with those from benchmarks or passive management, Sharpe $(1991 ; 1992 b)$ pointed out that, in order to add value, a mutual fund must 
differentiate benchmarks increasing idiosyncratic risk. In this regard, Kacperczyk et al. (2005) submitted that, on average, mutual funds that decide to deviate from the benchmark and concentrate their holdings on industries where they have informational advantages, perform better. In addition, Busse et al. (2007) document a positive relation between mutual fund performance and managers' willingness to take big bets in a relatively small number of stocks. Huij and Derwall (2011) found that concentrated funds with higher levels of tracking error display better performance than their more broadly diversified counterparts.

According to the literature cited previously, in order to add value, the manager must implement strategies or bets based on differentiation towards a benchmark or market that proxies passive investment. Thus, as indicated in the following equation, the performance of a given fund, $p$ (i.e. $\alpha_{p}$ ) is equivalent to aggregating the performance of each bet, $j$, in the market $m\left(\alpha_{p, j, m}\right)$. Therefore, not unlike Grinold and Kahn (2000) we modeled the performance as a function of the number of bets. Specifically, the fund's performance can be defined as:

$$
\alpha_{p}=\sum_{m} \sum_{j} \alpha_{p, j, m}
$$

The variable interacting with the bets is the managers' skill. Grinold and Kahn (2000) define it as the correlation between the forecast and the current value of the bet. We attempt to model managers' success according to two variables as follows:

$$
\alpha_{p, j, m}=f\left(c_{m}, v_{p, j, m}\right)
$$

The first one, $c_{m}$, is the number of opportunities in the market. If we think of the market as a game, then $c_{m}$ could be the game's ability to generate opportunities for success among its players. The second variable, $v_{p, j, m}$ is the relative ability of the managers of portfolio $p$ with respect to bet $j$ in market $m$. The ability of managers, as players, is a direct result of their training, experience, and information obtained from the market. It can be measured in relative terms with respect to the rest of the participants in a given market, both individual and professional investors-including among the latter, fund managers. Therefore, the performance corresponding to the bets has a direct relation to the level of opportunities in a given market $\left(c_{m}\right)$ as well as the manager's relative ability $\left(v_{p, j, m}\right)$. In line with this, we can show how managers' performance for a given portfolio $p$ with respect to a bet $j$ in market $m$ could be expressed as follows:

$$
\alpha_{p, j, m}= \begin{cases}f_{h}\left(c_{m}, v_{p, j, m}\right) & \text { if } c_{m}>c \\ f_{l}\left(c_{m}, v_{p, j, m}\right) & \text { if } c_{m} \leq c\end{cases}
$$

where $c$ is a parameter classifying markets between those with a high number of opportunities $\left(c_{m}>c\right)$ and those with a low number of opportunities $\left(c_{m} \leq c\right)$. The former are usually those with a high level of systematic risk, which offer fewer opportunities for success than the latter, with more specific risk and even incomplete securitization. The type of market (or game) conditions the expression (4) for markets 
with a lower number of opportunities $f_{h}(\cdot)$ or for markets with a low number of opportunities $f_{l}(\cdot)$. In this context, the effect of the relative ability $\left(v_{p, j, m}\right)$ of managers or players in the game (market) will be different. Hence, our hypothesis implies that in markets with a higher (lower) number of opportunities the relative ability of managers is more (less) relevant. We can model this as follows:

$$
\frac{\partial f_{h}\left(c_{m}, v_{p, j, m}\right)}{\partial v_{p, j, m}}>\frac{\partial f_{l}\left(c_{m}, v_{p, j, m}\right)}{\partial v_{p, j, m}}
$$

Thus, in markets with high specific risk and, consequently, a higher number of opportunities, it is possible that managers with greater ability have a better prospect of achieving persistent performance over time. As already noted, studies such as those by Sharpe (1991; 1992b), Kacperczyk et al. (2005), Busse et al. (2007) and Huij and Derwall (2011) point out how bets involving differentiation, concentration and, consequently, idiosyncratic risk, are among the elements that enable the existence of abnormal performance.

In contrast, the level of systematic risk is greater in markets with higher levels of securitization and more highly correlated assets, which decreases the number of opportunities. This means that the ability of managers is not as relevant a variable as it would be in a market with opportunities. A market with these characteristics could be compared to a game in which the result is, to a large extent, random, making it difficult for the ability of managers to obtain positive abnormal performance which persists over time.

The results from the literature on mutual fund performance in the most developed markets affirm this view. Most of the funds achieve a non-zero performance; nevertheless more cases of negative performance appear, finding evidence of underperformance at the aggregate level. A market with these characteristics, with high systematic risk and a low number of opportunities can motivate managers to show greater concern for improving their ability to select bets that can beat the market.

This has two effects. Firstly, it can facilitate reaching a certain limit at which the level of ability cannot be improved and, therefore, there might be few differences in the relative ability of most managers $\left(v_{p, j, m}\right)$. This, together with a low number of opportunities, would in fact imply that there are no big differences in the performance achieved and, therefore, there is no evidence of persistence. Secondly, some managers, under the pressure of a market with limited opportunities, could take highly risky bets. If it really is a market with limited opportunities it will be difficult to improve the results of the efficient frontier composed by systematic risk investments. In this situation it is likely that the specific risk will not be rewarded by the market, in other words, meaning that riskier bets imply worse performance. For this type of manager, the market would be comparable to participation in a game with few opportunities and expert players. In this context, some less experienced players who assume greater risks could experience big losses. Furthermore, players who are losers at some point could select risky bets to improve their position. Thus, Brown and Goetzmann (1995) find that mid-year losers tend to increase fund volatility during the latter part of an annual assessment period to a greater extent than mid-year winners. Kempf et al. (2009) also highlighted that when fund managers' employment risk is 
low, compensation incentives become more relevant and managers with a poor mid-year performance increase risk to catch up with the mid-year winners. In short, in a market with low specific risk and, therefore, a low number of opportunities, we generally expect a low level of persistence except for the case of the worst mutual funds; because their risky bets, instead of beating the market or improving their ranking in the mutual fund industry's tournament, lead to the opposite effect, i.e. their performance worsens.

\subsection{Performance persistence of Islamic mutual funds}

The traditional view of literature on performance persistence is that the mutual funds' performance does not persist in the long run (Hendricks et al., 1993; Elton and Gruber, 1996; Carhart, 1997; Pástor and Stambaugh, 2002; Berk and Green, 2004) . Nonetheless, the existence of mutual funds' shortrun performance persistence was documented in recent studies (Bollen and Busse, 2005b; Busse and Irvine, 2006; Huij and Verbeek, 2007; Gregory and Whittaker, 2007). The advocates of no persistence in performance articulate their argument with several reasons inter-alia higher amounts of fund flows may lead to a decreasing returns to scale; high management fees and other costs; lack of management skills; and the momentum effect. On the other hand the persistence in the short-run may stem from non-managerial change and lack of cash inflow. For example, outperforming fund managers may close the funds to new investor in order to protect their performance from the effect of cash inflow that leads to decreasing returns to scale Bris et al. (2007). It is also evident that changing the manager of an outperforming fund has a deteriorating effect on funds' performance post-replacement Khorana (2001). In the case of losers or underperformers, the majority of these funds are not able to improve performance in the short-run while few of them may do. This in turn may cluster persistence around the loser funds or underperformers (Brown and Goetzmann, 1995; Carhart, 1997). In addition, higher transaction cost, asymmetry of information regarding alternative funds and lack of investor's expertise may force investors to stick with underperforming funds thus has disequilibrium effect on the fund flows mechanism and consequently lead to poor performance persistence (Carhart, 1997; Berk and Tonks, 2007).

Our argument of the presence of persistence in Islamic funds' performance is intuitively motivated and supported by the literature findings. The stylized facts discussed earlier direct us toward four driving factors that are highly likely to cause persistence in the short-run for Islamic funds: i) the constraint investment horizon of these funds; ii) lack of managerial skills; iii) lack of alternative funds; iv) and lack of investor's expertise.

Pertaining to the objectives of the study - the analysis of the persistence of Islamic funds-we must consider the effect derived from the investment objectives. These funds pose constraints on certain types of investment. However, the contexts in which Islamic funds practice these constraints deserve a careful examination. Specifically, their constraints do not boil down to specific investments but are integrated in markets which have segments (assets) that are Shari'ah compliant. Islamic funds are restricted to equity 
investments with leverage (debts) not exceeding a certain threshold prescribed by their SSB. They also reject investments earning fixed income; for example, certain derivatives, such as options; CDs, or certificates of deposit; preferred stocks; and corporate bonds. In this sense, Askari et al. (2010) pointed out how factors explaining systematic risk in conventional finance-interest rates and credit booms that create a large equity premium - are absent in Islamic finance. As a result, asset prices in Islamic finance feature a very low correlation with the market portfolio and are influenced more by idiosyncratic risk from some characteristics of the firm, such as competitiveness, cost-efficiency and investment plans.

The equity returns are comprised mainly of dividends, so equity prices show higher stability without systematic trends, displaying high predictability and very low uncertainty. Therefore, given our theoretical approach developed from expressions (2) to (5), we expect that the evidence of persistence of Islamic funds meets the provisions for markets with higher idiosyncratic risk and a higher number of opportunities, while for other types of ethical funds (such as SRI funds) it conforms to that pointed out for the case of markets with higher systematic risk and a lower number of opportunities. Accordingly, a higher level of persistence is expected from Islamic funds, not only compared to their conventional counterparts but also compared to other types of constrained investments. This would occur because, compared to both their conventional and other constrained investments, Islamic funds invest in markets with higher specific risk, a higher number of opportunities and higher stability. By prohibiting speculative transactions and investments in highly leveraged firms and conventional banks, Islamic finance managed to maintain minimum exposure during the global financial crisis (Ahmed, 2010). We therefore expect Islamic funds to show resilience during the crisis.

The constraint investment horizon of Islamic funds may lead to persistence performance hence the limited maneuverability of the fund's managers to restructure her investment portfolio. Such limitation seems to be augmented in the case of Islamic funds; hence the screening criteria not only have social and ethical dimensions, but they also have financial criteria (i.e. a cap on liquidity and capital structure). The fund manager of an Islamic fund has to choose from firms with symmetrical capital structure, in other words with a capped financial leverage that is likely to, cæteris paribus, cluster the systematic risk of the portfolio within a certain range. For example Bauer et al. (2005) find ethical mutual funds less open to variability of market returns compared to conventional funds which might lead to persistence. Therefore persistence in performance is likely to be observed in these funds in the short-run.

In addition, Hoepner et al. (2011) argue that the constraints imposed on Islamic fund managers limit their ability to exploit both superior information and winning markets (Bollen and Busse, 2001; Kosowski et al., 2006)). On the other hand, these constraints limit the potential damage (Hoepner et al., 2011) which can be caused by unconstrained fund managers (Abdullah et al., 2007). Theoretical models (Barber and Odean, 2001) and empirical evidence (Puetz and Ruenzi, 2011) reveal that overconfident fund managers tend to trade excessively more than can be justified on rational grounds (Barberis and Thaler, 2003). This could potentially lead to volatility in performance if overconfident managers take bets outside the normal risk tolerances. Due to the constraints imposed on the managers of Islamic funds, it could be argued that they may be more careful as compared to their conventional counterparts 
in selecting firms to be included in their portfolio then avoiding volatility in performance. Moreover, trading constraints restrict the ability to exhibit the exuberant behavior of unconstrained investors, which is expected to lead to persistence in future performance.

Islamic funds require specialized managers with specific expertise in order to be able to deal with the investment requirements of such funds. These funds require extra-financial research aimed at understanding corporations performance in terms of environmental, social, and governance (ESG) issues in addition to the Shari'ah compliance rules for Islamic funds (Derigs and Marzban, 2008; Bauer et al., 2005). These requirements make it difficult to find good fund managers. Suffice it to say, any management company is highly likely to put maximum efforts to keep outperforming managers from moving to other companies. Khorana (2001) finds that changing the manager of an outperforming fund has a deteriorating effect on funds' performance post-replacement and thus eliminates any evidence of performance persistence. The market conditions for Islamic funds managers mitigate the possibility of outperforming managers due to the high retention forces by the management companies and may consequently lead to persistence in performance.

The lack of alternative funds is directly related to the cash flow of the funds. Hence, underperforming funds in the short-run may face cash outflow, provided the transaction cost for the client is less than the expected loss in the long-run. Despite the high growth in SRI and Islamic funds in the last two decades, there is still a significant gap between these funds and the conventional funds. The lack of alternative funds is likely to hinder the cash outflow for underperforming funds and thus contributes to persistence in the short-run. Similarly to the lack of investor expertise, Islamic funds as elaborated earlier require special expertise not only in financial and investment aspects but also in ESG issues and Shari'ah rules. This aspect is linked to information asymmetry and the market inefficiency argument by Grossman and Stiglitz (1980) and Glosten (1989). They clarify that various trading motives by investors may lead to market inefficiency hence investors will trade either for liquidity or informational reasons. In that case investors who do not have access to complete information may suffer from negative returns as compared to informed ones. The rational for Islamic funds is to maintain the experts who have the know-how and the capabilities to manage their funds rather efficiently. This factor is likely to provide a solid hurdle for Islamic funds' investors to withdraw funds even in case of underperformance, thus persistence takes place in such a case. It could also be argued that investors in SRI funds generally and Islamic funds specifically are expected to be relatively more loyal than their conventional counterparts (Webley et al., 2001). In addition, the non-financial Shari'ah screening criteria and hence firm inclusion/exclusion from the portfolio ${ }^{3}$ are less likely to change. These factors could lead to an expectation of portfolio stability as well as performance persistence.

\footnotetext{
${ }^{3}$ Unless the firm exceeds the financial ratio (such as gearing) thresholds.
} 


\section{Data description}

The data used in this study was taken from Shari'ah-compliant equity mutual funds. To be more specific, we analyzed 335 mutual funds classified as Islamic equity funds, classified according to Morningstar categories. This database provides information on daily returns for these funds. The analyzed sample period stretches from January $1^{\text {st }} 2000$ to June $30^{\text {th }} 2013$. We have reported some characteristics of the funds in our sample in Tables 1 through 4.

The evolution of the number of funds from the year 2000 up to 2013 is reported in Table 1. The number of funds varies over the sample period. This is due to the fact that some funds disappear and new ones are incorporated. Considering the net balance of newly born and dead mutual funds, the number is generally increasing. The annual increase in the number of funds has been positive over the entire period (2000-2013), with a pace which has been particularly high-the average growth was of 18.83\% per annum. Except for some particular years (2010 and 2012), these funds have been quite resistant to the crisis, since the number has more than doubled since the beginning of the international financial crisis.

There is no survivorship bias in the results for performance and persistence, because the existing funds during the sample period considered were included in the analysis. However, avoiding survivorship bias can also lead to other problems which are not addressed in the literature. Specifically, the inclusion of funds with limited data may reduce the robustness of the analysis. In this regard, Rohleder et al. (2011) pointed out how individual fund performance measurement requires a return history of a certain length to generate reliable regression estimates. In addition, comparing funds with different periods of existence could add some bias if the mutual fund's performance is correlated with the period for which data is available-for instance, the performance could differ depending on the economic cycle or for bull and bear markets (Kacperczyk et al., 2009; Kosowski, 2011; Sun et al., 2013). In order to avoid this type of problem, our empirical strategy will take into account the following: (i) according to the traditional mutual fund literature and eliminating survivorship bias, we present performance and persistence results for both groups jointly, i.e. all mutual funds and surviving funds; (ii) we also report results distinguishing between both groups, since it allows us to compare the results of the analysis of survivor and non-survivor funds for common periods.

Rohleder et al. (2011) analyzed survivorship bias in mutual fund performance with respect to four different fund groups: full-data survivors, non-full-data survivors, disappeared new funds and disappeared initial funds. In this line, Table 2 reports information on the different sub-types of funds considered in the study according to their survivorship characteristics. In particular, we create five categories of mutual funds. First, we split the funds into two sets, survivors $(S)$ and non-survivors (NS). The difference between the two sets is that the first (second) includes all the mutual funds with (without) a net asset value as of June $30^{\text {th }} 2013$ bearing in mind the number of semesters for which data for mutual funds are available, we distinguished three subgroups for $S$ mutual funds: $S=27$, when the fund shows data for the whole sample period, i.e. 27 semesters; $S \geq 4$ for survivor mutual funds with 
at least four semesters of data, and $S<4$ for survivors less than four semesters old. Also, considering semesters with data, non-survivor mutual funds are collated into two groups, NS $\geq 4$ is constituted by mutual funds with at least four semesters of data, and $N S<4$ for the rest. As indicated in Table 2, only $5.67 \%(19 / 335)$ of the funds have complete data over the period sample $(S)$. The largest group is that denoted by $S \geq 4$, specifically $52.84 \%$ (177/335) of the funds.

Table 3 reports some summary statistics corresponding to the mutual funds' sample. With respect to the geographic area of investment, most funds (262 out of 335, representing $78.21 \%$ of the total) focus on Europe, the US and Canada. However, according to a mean-variance analysis, the differences among both categories analyzed, on average, are low. Differences are only notable in the average size of the funds, which is more than 50\% higher in the case of Middle East OE Equity.

As mentioned in the methodology section, to evaluate mutual fund performance we apply a linear model where funds' excess returns are adjusted to the excess returns corresponding to the types of assets in which the funds invest. It should be noted that the analyzed funds invest in very different geographical areas so that the first benchmark is a global index representing global investmentsspecifically the FTSE World. To represent the Shari'ah compliant investments we have selected the DJ Islamic World. Moreover, since a significant number of funds have specific investment in the Middle East, we have also selected the FTSE AW Middle East \& Africa. To compute the excess return we have the one-month Treasury bill rate as the risk-free asset, which we obtained from Ken French's website. ${ }^{4}$

Table 4 reports the indexes used in expression (1) for the funds in the sample. Furthermore, summary statistics for the indexes for the analyzed sample period, the most globalized indexes (for which financial markets in more advanced economies weigh more) show a more conservative mix of average return and risk compared to those for emerging markets (FTSE AW Middle East\&Africa and FTSE Emerging markets indexes) for which there is higher risk and, most importantly, average return.

\section{Results}

\subsection{Results on performance}

Table 5 shows the results of the estimation of the fund performance obtained by applying model (1). The results were grouped by Morningstar category and the average for all the funds is reported at the bottom. The left panel of the table indicates that, for Europe OE Islamic Equity funds, the positive or negative abnormal performance is distributed similarly, albeit the percentage of funds that are significantly different from zero is small: $4.58 \%$ (6.49\%) for the abnormal negative (positive) performance. For Middle East OE Equity funds, the percentage of funds with positive alphas is higher; however, the proportion of funds with significantly negative abnormal performance $(5.48 \%)$ is higher compared to those who obtain a positive and significant alpha $(2.74 \%)$. The sum of both categories of funds shows how the number of significant alphas is very small and almost equal for those with negative and positive signs ( $4.78 \%$ and $5.67 \%$, respectively).

\footnotetext{
${ }^{4}$ See http://mba.tuck.dartmouth.edu/pages/faculty/ken.french/data_library.html.
} 
The right panel of Table 5 shows aggregate information on the performance achieved for Islamic funds. We reported the annualized performance from daily abnormal alpha, being $-0.27 \%$ for Europe OE funds and 3.19\% for the Middle East OE funds. The results achieved for Europe OE funds coincide with most previous studies which have evaluated mutual fund performance that is close to zero on the left. However, Middle Eastern funds attained a relatively high average performance and, therefore, it would appear that their managers have the ability to add value. The value of the median is similar to the sample mean in the case of Europe OE funds ( $-0.27 \%$ vs. $-0.23 \%)$, suggesting that the performance differences within this category of funds are relatively low. However, compared with the mean, the median is lower for Middle East OE Equity funds, which indicates that the mean is shifted to the right due to the abnormal performance of some funds. The next column shows funds' abnormal performance normalized by size (measured by assets)-i.e. a size-weighted average. This value is interesting because it indicates the abnormal performance obtained on average for every dollar invested in this group of funds. Both types of funds' alphas increase remarkably, suggesting that larger funds are achieving better performance with respect to smaller funds.

Furthermore, the last column of Table 5 shows the performance, taking time into account, during which the investment fund is alive-i.e., it reports a weighted average in which the weighting factor is the fund's life. We consider this calculation as important, since the number of funds is increasing during the sample period and the unweighted mean might be influenced by funds with a limited life. This would somehow distort the representativeness of the mean as a measure of abnormal performance for these particular funds. In the case of Europe OE Islamic Equity funds, the time-weighted alpha funds take a value of $1.65 \%$, which represents a significant increase when compared with the unweighted mean, which was $-0.27 \%$. This implies that funds with greater presence during the sample period provide some added value and that the impact of funds with less presence, either because they have disappeared, or because they are new, contributes to a negative final value for the mean. However, in the case of Middle East OE Equity funds, the effect is the opposite. In summary, data in the right panel of Table 5 shows that the average abnormal performance for Europe OE Islamic Equity funds is adversely affected by smaller funds or those with less "presence" (in terms of time) during the sample period. In the case of the Middle East OE Equity funds, their abnormal performance is also negatively affected by smaller sized funds, but positively affected by funds with less presence.

Regarding the effect of size on performance, there is evidence of an improvement of the average abnormal performance when weighting by fund size. This result is evident for the entire category of Islamic funds as well as for each type of fund according to its geographical investment area. This would imply that a certain positive relationship between performance and size exists, so that smaller (larger) funds show worse (better) performance. The empirical evidence on the link between performance and size is mixed. Our results are in line with Indro et al.'s (1999) approach, as well as the empirical evidence found by Otten and Bams (2004) and Rohleder et al. (2011), among others. 


\subsection{Comparing survivors' and non-survivors' performance}

According to the sections above, funds' performance changes when controlling for both fund size and life. Both weighting schemes are relevant, nonetheless the literature on mutual fund performance has demonstrated that survivorship is also a relevant issue (see, for instance, the influential study by Brown et al., 1992, among other relevant contributions). Therefore, we conducted a detailed comparative analysis of funds' performance taking survivorship into account in Table 6. In order to do this, we used the clustering of funds considered in Table 2, i.e. we distinguished between five groups of funds depending on their survivorship characteristics. Accordingly, survivor funds, i.e. those existing at the end of the sample period, are divided into three groups: those with complete data for the entire period (i.e. they are alive during the $S=27$ semesters of the sample study), those for which data exist for at least four semesters $(S \geq 4)$ and those whose life is lower than this time horizon $(S<4)$. The funds that did not survive are divided among those with more than four semesters with data (NS $\geq 4$ ) and those with a lower time horizon (NS $<4$ ).

Table 6 compares the performance of these groups of funds. We have set the funds surviving over four semesters $(S \geq 4)$, since it is the largest group. The tables show the difference between the performance of each group and the group $S \geq 4$. The $p$-values corresponding to the abnormal performance differences between groups were computed using bootstrap. Table 6 shows that the performance of those funds with complete data $(S=27)$ is $1.31 \%$ higher than that of the reference group-yet the difference is not significant. However, for the rest of the groups the difference is negative and significant. Since there could be a pattern with respect to the geographical area in which the fund invests, we also carried out an analysis confining the comparison to funds investing in the same geographical area. Hence, we observed that those funds investing in Europe OE show the same pattern, but the difference is only significant for the non-survivors. Accordingly, non-survivor funds with more than four semesters (NS $\geq 4$ ) may obtain an abnormal performance of $-6.54 \%$ (annualized) with respect to reference survivor funds $(S \geq 4)$. The percentage is $-11.23 \%$ for non-survivor funds with shorter lives (i.e. NS $<4$ ). This might suggest that Islamic funds investing in Europe OE and non-survivor funds achieve worse performance than the survivors. In the case of the funds which invest in the Middle East (which is the smallest group), the differences are not significant.

One could conclude that for developed markets and for groups of funds with a large number, nonsurviving funds achieve worse performance than survivors. This evidence is similar to that from other studies on conventional mutual funds as shown by Malkiel (1995), Elton and Gruber (1996), Carhart et al. (2002) and Rohleder et al. (2011), among others.

\subsection{Persistence}

In this section we will assess persistence by analysing the performance of portfolios that invest according to the past. These results are reported in Tables 7 and 8 for all funds together and survivors only, respectively. 
We hypothesized that if there is persistence in mutual fund performance, a portfolio with investments based on a poor (good) past performance will show a negative (positive) abnormal performance (see Carhart, 1997; Busse et al., 2010, among others). This methodology was been applied taking into account both a half-yearly and a yearly window. In the former (latter) case, the sample period was divided into semesters (years) and we considered a strategy based on investing as a function of the previous semester's (year's) abnormal performance, which is revised each semester (year). First, we measured the abnormal performance of each fund using expression (1) in the first period. Second, funds were are ranked according to their performance and classified into deciles. Third, we built equally weighted portfolios which, during the following period, invested in the mutual funds according to their previous decile classification. For instance the first portfolio, $D_{1}$ (first decile) invested in the worst performing funds in the previous period and, conversely, the last portfolio, $D_{10}$, invested in the previous period's best funds. This procedure was applied again at the end of each period. By following this scheme, each portfolio from $D_{1}$ to $D_{10}$ followed an investment strategy that rebalances selected funds according to their previous abnormal performance. Taking into account the daily return of these portfolios we estimated their abnormal performance following (1); should it be significantly positive (negative) for the first (last) deciles, it will constitute evidence of persistence.

The first row in each of these tables shows the values of the abnormal performance of the decileportfolios. The second and third rows report the $p$-values for the estimates. Specifically, the second row reports the standard $p$-value from regression model (1) with the Newey-West heteroskedasticity and autocorrelation consistent covariance estimator. This standard $p$-value corresponds to testing if alpha is different from zero. The $p$-values in the third row, which we refer to as cross-sectional $p$-values, correspond to the critical probability estimated by means of simulations and corresponds to testing whether the alpha corresponding to the portfolio-decile (which corresponds to an investment strategy based on past performance) is different from that obtained when following a random strategy.

This second $p$-value is necessary to differentiate between the performance per se of the portfolio, compared with the performance achieved by following a strategy of investing in past best or worst mutual funds. We need to differentiate between the performance of the group of mutual funds and that achieved following a dynamic strategy based on past performance. In order to do this, we will form portfolios in the same way as the previous decile-portfolios based on past performance, with the difference that now the funds invested in will not be based on past performance, but selected randomly. If there is persistence in the added value from managers, the best or worst mutual funds will repeat that ranking in the future, and a strategy based on their past performance should achieve a better performance than a random strategy that invests in funds without any criteria.

5,000 synthetic equally-weighted portfolios were then formed that invested randomly in a decile of the group's funds. The daily returns of the synthetic portfolios were computed and model (1) was applied to estimate abnormal performance. Consequently, a distribution of 5,000 alphas was formed to test for the significance of the abnormal performance of following investment recommendations based on past performance. Next, for each of the portfolios based on past performance, the cross-sectional 
$p$-value was computed as the percentage of synthetic portfolios which produce an alpha greater than the corresponding value for that past-performance-based portfolio. This procedure was repeated for each of the different fund categories in Tables 7 and 8 (survivors/non-survivors). In summation, Tables 7 and 8 show two $p$-values, the first (the standard $p$-value) measuring whether the performance of the past-performance-based portfolio was significantly different from zero; the second, the cross-sectional $p$-value measures whether this performance was linked to investment in past best or worst mutual funds and, thus, if it was significantly different from the result of the investment per se in that group of funds.

Results were also split according to the time horizon. The upper (lower) panels in each of Table 7 and 8 present the results when a half-year (annual) window was used both to measure past persistence as well as to implement the investment strategy in the next period. Recall that the portfolio $D_{1}\left(D_{10}\right)$ is an investment strategy which selects the decile of the worst (best) funds in the previous semester. As noted, the abnormal performance of portfolios is increasing from $D_{1}$ to $D_{10}$. This implies some evidence of persistence in abnormal performance of the funds and to invest in the worst (best) funds in the past provides worse (better) results.

First, Table 7 shows performance results for the funds in the sample. The upper panel (Panel A) reports results when the windows for estimating both past performance and investment rebalancing are half-yearly. Its first row shows that abnormal performance is increasing across deciles. Figure 1 is its graphical counterpart and corroborates this behavior. This pattern is less clear for portfolios corresponding to the central deciles. Actually, the cross-sectional $p$-value for these portfolios points to an abnormal performance which is not significantly different from that obtained randomly. Anyway, the standard $p$-value indicates that the performance is only different from zero for significance levels between $5 \%$ and $10 \%$ for portfolios $D_{8}, D_{9}$ and $D_{10}$. The cross sectional $p$-value indicates that the performance is significantly different from that achieved following a random strategy. For these portfolios the annualized abnormal performances are $4.70 \%, 7.88 \%$ and $8.68 \%$, respectively. This would constitute evidence of persistence in performance for the best funds, implying that managers are capable of providing value added to the funds managed persistently over time. This result is in line with the results found in other studies such as Lynch and Musto (2003), Cohen et al. (2005) and Kosowski et al. (2006), who found persistence among winners. Such evidence is relevant to the extent that the investor should select the best funds from the past in order to obtain good performance in the future.

Panel B in Table 7 reports persistence results for all funds in the sample when the investment strategy following the past performance with a window is constructed yearly, both to measure funds' performance and to rebalance the portfolio. In this case the evidence of persistence is weaker. The corresponding trend that we observed in Panel A was increasing for portfolios of higher deciles in Panel B, however it was less clearly visible for the rest. In fact, the corresponding line in Figure 1 only shows positive trends for higher deciles. In reality, the standard and cross-sectional $p$-values in this panel show that the abnormal performance of decile-portfolios is not significant, except for $D_{10}$, which reaches an annualized value of $9.25 \%$. Comparing results for Panels A and B in Table 7, it looks like the 
higher persistence found in the upper panel is due to a short-term phenomenon. This result is in line with previous findings in the financial literature such as those by Deaves (2004) and Bollen and Busse (2005a), among others, who point out how a certain degree of performance persistence is revealed as a short-term phenomenon.

Table 8 shows results for persistence when only survivor funds with more than two years at the end of the period are considered (those named $S=27$ and $S \geq 4$ in Table 2) which would correspond to more stable funds. When a half-yearly window is used (Panel A), the increasing tendency observed in Table 7 is not as clear-especially for portfolios corresponding to the lower deciles. Nevertheless, for higher deciles' portfolios, i.e. $D_{8}, D_{9}$ and $D_{10}$ the abnormal performance is, respectively, $6.51 \%, 11.73 \%$ and $7.81 \%$, but it is only significant for the first two. Panel B in Table 8 shows results when the window used is yearly. Similar to what we obtained in Table 7, for a yearly window the evidence of persistence is weaker and only the $9.40 \%$ abnormal performance corresponding to portfolio $D_{10}$ is close to the $10 \%$ significance level.

To put it briefly, when analysing performance persistence we find a tendency indicating that investing in funds with worse (better) past performance results in worse (better) future performance, as shown in Figure 1. In section 3.3 we proposed that it was more likely to expect a higher level of persistence in Islamic funds than in their conventional or SRI counterparts, since the first ones invest in markets with higher idiosyncratic risk, a higher number of opportunities, and higher stability. In this sense, persistence is only significant in the case of the best Islamic funds, especially in the short term corresponding to a semester (half-year) window. Therefore, the skilled managers of those funds are able to select winning bets in a market with potential for success. Taking into account the role, in the analysis of persistence, of non-surviving funds with shorter lives, we observe that for these ones results are not substantially changed. However, the evidence of persistence is slightly worse when they are not taken into account. The last result is coincidental with the evidence reported by Carhart et al. (2002), who found that controlling for survivorship weakens the evidence of persistence.

\section{Conclusions}

The literature on mutual fund performance persistence is now well-established. However, the question as to whether some mutual fund managers possess significant abilities which persist over time is still under debate-i.e. if the "astute" investor is able to predict future performance based on past results. In summary, it is generally argued that this question cannot be answered either positively or negatively, rather it is subject to several nuances.

We have analyzed the performance persistence of Islamic funds, a particular type of ethical funds. Despite their growing importance, the attention that the finance literature has given them is low compared to the high number of studies focusing on conventional funds. Simultaneously, the attention devoted to Islamic funds compared to either conventional or SRI funds has also been low. In the case of Islamic funds, their growth has not only been remarkable but also presents some interesting particu- 
larities because, despite the disruption of the 2007-2008 financial crisis affecting the observed trend for most financial services worldwide, these types of investments were able to maintain their growth with the number of this type of funds growing, on average, 16.65\% per annum in the 2008-2013 period.

Taking these premises into consideration, the paper has had two aims, one substantive and one methodological. Our first, substantive aim has been to conduct an analysis of performance persistence of Islamic funds for the 2000-2013 periods. As indicated above, the issue as to whether it is possible to predict future performance based on past results is still virtually unexplored for this type of investments. Our second, methodological, aim has been to consider a different procedure for measuring mutual fund performance persistence compared to the most extended methods in the literature. Specifically, we have designed an algorithm based on the recursive investment portfolio approach initially proposed by Carhart (1997), which we refine by proposing an alternative procedure to ascertain whether the abnormal performance found results from a dynamic investment strategy (based on past returns) or not. In addition, persistence was calculated for two types of periodicity-semiannual (halfyearly) and annual, and the results were reported for both surviving and non-surviving funds.

Results show that, when analysing whether "ethical money" is sensitive to past returns, it is relevant to distinguish within ethical categories, as shown by our analysis for Islamic funds. Although our general findings indicate that persistence exists, results are subject to several subtleties. In general, past returns are important for this type of investment, particularly for the highest deciles-i.e. the best funds-whereas for the worst ones results were not significant. In addition, both the time horizon considered and survivorship bias were factors to be controlled for (persistence weakens when non-surviving funds are not taken into account). Therefore, our results support previous evidence found on the role of nonfinancial attributes when evaluating fund performance and, in addition, they provide evidence regarding how important it is to distinguish within ethical funds' categories. This finding would constitute evidence in favor of how different screening processes may generate valuerelevant information for investors which, as indicated by Renneboog et al. (2011), would not be available otherwise.

This research also constitutes empirical evidence supported the shared view (Askari et al., 2010) that Islamic banking and finance are more resilient in crisis times. This could be explained that by prohibiting speculative transactions and investments in highly leveraged firms and conventional banks, Islamic funds managed to maintain minimum exposure and suffered less during the global financial crisis (Ahmed, 2010). This is partly supported by our results as Islamic funds showed resilience during the crisis. Regarding the performance persistence issue, our results support performance persistence of Islamic funds which could be due to many factors, including the constrained investment horizon and the specialist managerial skills needed for these funds, in addition to the lack of alternative funds and loyalty of their investors. Our results have implications for international investors, practitioners and researchers in considering the impact of the unique characteristics of this class of ethical funds. 


\section{References}

Abdelsalam, O., Duygun, M., Matallín-Sáez, J. C., and Tortosa-Ausina, E. (2014a). Do ethics imply persistence? The case of Islamic and socially responsible funds. Journal of Banking \& Finance, 40:182-194.

Abdelsalam, O., Fethi, M. D., Matallín, J. C., and Tortosa-Ausina, E. (2014b). On the comparative performance of Socially Responsible and Islamic mutual funds. Journal of Economic Behavior E Organization, 103:S108-S128.

Abdullah, F., Hassan, T., and Mohamad, S. (2007). Investigation of performance of malaysian islamic unit trust funds: Comparison with conventional unit trust funds. Managerial Finance, 33(2):142-153.

Ahmad, Z. and Ibrahim, H. (2002). A study of performance of the KLSE Shariah Index. Malaysian Management Journal, 6:25-34.

Ahmed, A. (2010). Global financial crisis: an Islamic finance perspective. International Journal of Islamic and Middle Eastern Finance and Management, 3(4):306-320.

Alam, N., Tang, K. B., and Rajjaque, M. S. (2013). A comparative performance of conventional and Islamic unit trusts: Market timing and persistence evidence. Journal of Financial Services Marketing, 18(4):316-326.

Albaity, M. and Ahmad, R. (2008). Performance of Syariah and composite indices: Evidence from Bursa Malaysia. Asian Academy of Management Journal of Accounting and Finance, 4(1):23-43.

Askari, H., Iqbal, Z., Krichene, N., and Mirakhor, A. (2010). The Stability of Islamic Finance. Wiley Finance. Wiley, Singapore.

Avramov, D. and Wermers, R. (2006). Investing in mutual funds when returns are predictable. Journal of Financial Economics, 81(2):339-377.

Barber, B. and Odean, T. (2001). Boys will be boys: Gender, overconfidence, and common stock investment. Quarterly Journal of Economics, 141:261-292.

Barberis, N. and Thaler, R. (2003). A survey of behavioral finance. In Constantinides, G. M., Harris, M., and Stulz, R., editors, Handbook of the Economics of Finance, volume 1, chapter 18, pages 1053-1128. Elsevier, Amsterdam.

Barras, L., Scaillet, O., and Wermers, R. (2009). False discoveries in mutual fund performance: Measuring luck in estimated alphas. Journal of Finance, 65(1):179-216.

Bauer, R., J. Derwall, J., and Otten, R. (2007). The ethical mutual fund performance debate: New evidence from Canada. Journal of Business Ethics, 70:111-124.

Bauer, R., Koedijk, K., and Otten, R. (2005). International evidence on ethical mutual fund performance and investment style. Journal of Banking E Finance, 29(7):1751-1767.

Berk, J. B. and Green, R. C. (2004). Mutual fund flows and performance in rational markets. Journal of Political Economy, 112(6):1269-1295.

Berk, J. B. and Tonks, I. (2007). Return persistence and fund flows in the worst performing mutual funds. Working Paper 13042, National Bureau of Economic Research, Cambridge, MA. 
BinMahfouz, S. and Hassan, M. K. (2012). A comparative study between the investment characteristics of Islamic and conventional equity mutual funds in Saudi Arabia. The Journal of Investing, 21(4):128-143.

Bollen, N. and Busse, J. (2001). On the timing ability of mutual fund managers. Journal of Finance, 56(3):1075-1094.

Bollen, N. and Busse, J. (2005a). Short-term persistence in mutual fund performance. Review of Financial Studies, 18(2):569-597.

Bollen, N. P. B. and Busse, J. A. (2005b). Short-term persistence in mutual fund performance. Review of Financial Studies, 18(2):569.

Bris, A., Gulen, H., Kadiyala, P., and Rau, P. (2007). Good stewards, cheap talkers, or family men? The impact of mutual fund closures on fund managers, flows, fees, and performance. Review of Financial Studies, 20(3):953-982.

Brown, S., Goetzmann, W., Ibbotson, R., and Ross, S. (1992). Survivorship bias in performance studies. Review of Financial Studies, 5(4):553-580.

Brown, S. J. and Goetzmann, W. N. (1995). Performance persistence. Journal of Finance, 50:679-698.

Busse, J. A., Clifton, G. T., and Klaas, B. (2007). Fund managers who take big bets: skilled or overconfident. In AFA 2007 Chicago Meetings Paper, available at SSRN: http://ssrn.com/abstract=891727.

Busse, J. A., Goyal, A., and Wahal, S. (2010). Performance and persistence in institutional investment management. Journal of Finance, 65(2):765-790.

Busse, J. A. and Irvine, P. J. (2006). Bayesian alphas and mutual fund persistence. The Journal of Finance, 61(5):22512288.

Carhart, M. M. (1997). On persistence in mutual fund performance. Journal of Finance, 52(1):57-82.

Carhart, M. M., Carpenter, J. N., Lynch, A. W., and Musto, D. K. (2002). Mutual fund survivorship. Review of Financial Studies, 15(5):1439-1463.

Cohen, R. B., Coval, J. D., and Pástor, L. (2005). Judging fund managers by the company they keep. Journal of Finance, 60(3):1057-1096.

Cuthbertson, K., Nitzsche, D., and O'Sullivan, N. (2008). UK mutual fund performance: Skill or luck? Journal of Empirical Finance, 15(4):613-634.

Deaves, R. (2004). Data-conditioning biases, performance, persistence and flows: The case of Canadian equity funds. Journal of Banking \& Finance, 28(3):673-694.

Derigs, U. and Marzban, S. (2008). Review and analysis of current Shariah-compliant equity screening practices. International Journal of Islamic and Middle Eastern Finance and Management, 1(4):285-303.

Dharani, M. and Natarajan, P. (2011). Equanimity of risk and return relationship between Shari'ah index and general index in India. Journal of Economics and Behavioral Studies, 2(5):213-222.

Elton, E. and Gruber, M. (1996). The persistence of risk-adjusted mutual fund performance. Journal of Business, 69(2):133-157. 
Elton, E. J., Gruber, M. J., and Blake, C. R. (1996). The persistence of risk-adjusted mutual fund performance. Journal of Business, 69(2):133-157.

Elton, E. J., Gruber, M. J., Das, S., and Hlavka, M. (1993). Efficiency with costly information: A reinterpretation of evidence from managed portfolios. Review of Financial Studies, 6(1):1-22.

Ernst \& Young (2011). Islamic Funds \& Investments Report 2011: Achieving Growth in Challenging Times.

Fama, E. F. and French, K. R. (1993). Common risk factors in the returns on stocks and bonds. Journal of Financial Economics, 33(1):3-56.

Fama, E. F. and French, K. R. (2010). Luck versus skill in the cross-section of mutual fund returns. Journal of Finance, 65(5):1915-1947.

Girard, E. C. and Hassan, M. K. (2008). Is there a cost to faith-based investing: Evidence from FTSE Islamic indices. The Journal of Investing, 17(4):112-121.

Glosten, L. R. (1989). Insider trading, liquidity, and the role of the monopolist specialist. Journal of Business, 62:211-235.

Godlewski, C. J., Turk-Ariss, R., and Weill, L. (2013). Sukuk vs. conventional bonds: A stock market perspective. Journal of Comparative Economics, 41(3):745-761.

Goetzmann, W. N. and Ibbotson, R. G. (1994). Do winners repeat? Journal of Portfolio Management, 20(2):9-18.

Gregory, A. and Whittaker, J. (2007). Performance and performance persistence of "ethical" unit trusts in the UK. Journal of Business Finance \& Accounting, 34(7-8):1327-1344.

Grinblatt, M. and Titman, S. (1992). The persistence of mutual fund performance. Journal of Finance, 47(5):1977-1984.

Grinblatt, M. and Titman, S. (1993). Performance measurement without benchmarks: An examination of mutual fund returns. Journal of Business, 66(1):47-68.

Grinold, R. (1989). The fundamental law of active portfolio management. Journal of Por, 15:30-37.

Grinold, R. and Kahn, R. (2000). Active portfolio management: A quantitative approach for producing superior returns and controlling risk. McGraw-Hill, New York.

Grossman, S. J. and Stiglitz, J. E. (1980). On the impossibility of informationally efficient markets. American Economic Review, 70(3):393-408.

Hashim, N. (2008). The ftse global islamic and the risk dilemma. Working Paper Series 2008-08, American International University, Office of Research and Publications (ORP), Bangladesh.

Hayat, R. and Kraeussl, R. (2011). Risk and return characteristics of Islamic equity funds. Emerging Markets Review, 12(2):189-203.

Hendricks, D., Patel, J., and Zeckhauser, R. (1993). Hot hands in mutual funds: Short-run persistence of relative performance, 1974-1988. Journal of Finance, 48(1):93-130. 
Hiagh, M. and Hazelton, J. (2004). Financial markets: A tool for social responsibility. Journal of Business Ethics, 52(1):59-71.

Hoepner, A. G. F., Rammal, H. G., and Rezec, M. (2011). Islamic mutual funds' financial performance and international investment style: evidence from 20 countries. The European Journal of Finance, 17(9-10):829-850.

Huij, J. and Derwall, J. (2011). Global equity fund performance, portfolio concentration, and the fundamental law of active management. Journal of Banking \& Finance, 35(1):155-165.

Huij, J. and Verbeek, M. (2007). Cross-sectional learning and short-run persistence in mutual fund performance. Journal of Banking E Finance, 31(3):973-997.

Indro, D. C., Jiang, C. X., Hu, M. Y., and Lee, W. Y. (1999). Mutual fund performance: does fund size matter? Financial Analysts Journal, 55(3):74-87.

Jegadeesh, N. and Titman, S. (1993). Returns to buying winners and selling losers: Implications for stock market efficiency. Journal of Finance, 48(1):65-91.

Jensen, M. C. (1968). The performance of mutual funds in the period 1945-1964. Journal of Finance, 23:389-416.

Kacperczyk, M., Sialm, C., and Zheng, L. (2005). On the industry concentration of actively managed equity mutual funds. Journal of Finance, 60(4):1983-2011.

Kacperczyk, M., Van Nieuwerburgh, S., and Veldkamp, L. (2009). Rational attention allocation over the business cycle. Working Paper 15450, National Bureau of Economic Research, Cambridge, MA.

Kempf, A., Ruenzi, S., and Thiele, T. (2009). Employment risk, compensation incentives, and managerial risk taking: Evidence from the mutual fund industry. Journal of Financial Economics, 92(1):92-108.

Khorana, A. (2001). Performance changes following top management turnover: Evidence from open-end mutual funds. Journal of Financial and Quantitative Analysis, 36(03):371-393.

Kosowski, R. (2011). Do mutual funds perform when it matters most to investors? US mutual fund performance and risk in recessions and expansions. Quarterly Journal of Finance, 1(3):607-664.

Kosowski, R., Timmermann, A., Wermers, R., and White, H. (2006). Can mutual fund "stars" really pick stocks? New evidence from a bootstrap analysis. Journal of Finance, 61(6):2551-2595.

Lynch, A. W. and Musto, D. K. (2003). How investors interpret past fund returns. Journal of Finance, 58(5):2033-2058.

Malkiel, B. G. (1995). Returns from investing in equity mutual funds 1971 to 1991. Journal of Finance, 50(2):549-572.

Mansor, F. and Bhatti, I. (2011). Risk and return analysis on performance of the Islamic mutual funds: evidence from Malaysia. Global Economy and Finance Journal, 4(1):19-31.

Massa, M. and Patgiri, R. (2009). Incentives and mutual fund performance: Higher performance or just higher risk taking? Review of Financial Studies, 22:1777-1815.

Novethic (2009). Islamic finance and SRI: any crossover? Unpublished manuscript. 
Otten, R. and Bams, D. (2004). How to measure mutual fund performance: economic versus statistical relevance. Accounting \& finance, 44(2):203-222.

Pástor, L. and Stambaugh, R. F. (2002). Investing in equity mutual funds. Journal of Financial Economics, 63(3):351380.

Puetz, A. and Ruenzi, S. (2011). Overconfidence among professional investors: Evidence from mutual fund managers. Journal of Business Finance \& Accounting, 38(5-6):684-712.

Quigley, G. and Sinquefield, R. (2000). Performance of UK equity unit trusts. Journal of Asset Management, 1(1):72-92.

Renneboog, L., Ter Horst, J., and Zhang, C. (2011). Is ethical money financially smart? Nonfinancial attributes and money flows of socially responsible investment funds. Journal of Financial Intermediation, 20(4):562-588.

Rohleder, M., Scholz, H., and Wilkens, M. (2011). Survivorship bias and mutual fund performance: Relevance, significance, and methodical differences. Review of Finance, 15(2):441-474.

Sauer, D. A. (1997). The impact of social-responsibility screens on investment performance: Evidence from the Domini 400 Social Index and Domini Equity Mutual Fund. Review of Financial Economics, 6(2):137-149.

Shanmugam, B. and Zahari, Z. (2009). A primer on Islamic finance. Research foundation publications, CFA Institute, Charlottesville.

Sharpe, W. (1992a). Asset allocation: Management style and performance measurement. Journal of Portfolio Management, 18(2):7-19.

Sharpe, W. F. (1991). The arithmetic of active management. Financial Analysts Journal, 47(1):7-9.

Sharpe, W. F. (1992b). Asset allocation: management style and performance measurement. Journal of Portfolio Management, 18(2):7-19.

Sun, Z., Wang, A., and Zheng, L. (2013). Only when the tide goes out: Downside returns and hedge fund performance. Working paper, SSRN. Available at SSRN: http://ssrn.com/abstract=2249033 or http:/ /dx.doi.org/10.2139/ssrn.2249033.

Webley, P., Lewis, A., and Mackenzie, C. (2001). Commitment among ethical investors: an experimental approach. Journal of Economic Psychology, 22:27-42.

Wermers, R. (2003). Is money really 'smart'? New evidence on the relation between mutual fund flows, manager behavior, and performance persistence. Available at SSRN: http://ssrn. com/abstract414420. 
Table 1: Evolution of the number of Islamic funds, 2000-2013

\begin{tabular}{lrr}
\hline \multirow{2}{*}{ Year } & \multicolumn{2}{c}{ Islamic } \\
\cline { 2 - 3 } $\begin{array}{c}\text { Number of } \\
\text { funds }\end{array}$ & \% change \\
\hline 2000 & 30 & - \\
2001 & 34 & 13.33 \\
2002 & 40 & 17.65 \\
2003 & 49 & 22.50 \\
2004 & 57 & 16.33 \\
2005 & 72 & 26.32 \\
2006 & 84 & 16.67 \\
2007 & 111 & 32.14 \\
2008 & 147 & 32.43 \\
2009 & 191 & 29.93 \\
2010 & 201 & 5.24 \\
2011 & 227 & 12.94 \\
2012 & 215 & -5.29 \\
2013 & 268 & 24.65 \\
\hline Mean \% change 2000-2013 & - & 18.83 \\
Mean \% change 2000-2008 & - & 22.17 \\
Mean \% change 2008-2013 & - & 16.65 \\
\hline
\end{tabular}


Table 2: Survival characteristics of mutual funds in the sample

\begin{tabular}{llrrrrrr}
\hline Type of fund & Morningstar Category & $S=27$ & $S \geq 4$ & $S<4$ & $N S \geq 4$ & $N S<4$ & Total \\
\hline \multirow{3}{*}{ Islamic } & Europe OE Islamic Equity $^{\mathrm{a}}$ & 12 & 137 & 37 & 53 & 23 & 262 \\
& Middle East OE Equity $^{\mathrm{b}}$ & 7 & 40 & 0 & 16 & 10 & 73 \\
\cline { 2 - 8 } & Total & 19 & 177 & 37 & 69 & 33 & 335 \\
\hline
\end{tabular}

a Europe OE Islamic Equity includes: (i) Europe OE Islamic Asia Pacific Equity; (ii) Europe OE Islamic Equity - Other; (iii) Europe OE Islamic Global Equity; (iv) Europe OE Islamic Malaysia Equity.

b Middle East OE Equity includes: (i) Middle East OE GCC Islamic Equity; (ii) Middle East OE Global Islamic Equity; (iii) Middle East OE Kuwait Islamic Equity; (iv) Middle East OE Saudi Islamic Equity. $S=27:$ Total survivor (present in the sample 27 semesters).

$S \geq 4$ : Mature survivor (present in at least 4 semesters (it has value for semester 27 , i.e. it is alive as of 30/06/2013).

$S<4$ : New survivor present in less than 4 semesters (it has value for semester 27 , i.e. it is alive as of 30/06/2013)

NS $\geq 4$ : Not survivor with at least 4 semesters (it has no value for semester 27, i.e. it is not alive as of $30 / 06 / 2013$ )

NS < 4: Not survivor with less than 4 semesters (it has no value for semester 27 , i.e. it is not alive as of $30 / 06 / 2013)$. 
Table 3: Mutual fund summary statistics, 2000-2013

\begin{tabular}{|c|c|c|c|c|c|c|}
\hline Type of fund & Morningstar category & $\begin{array}{l}\text { Number } \\
\text { funds }\end{array}$ & of & $\begin{array}{l}\text { Average an- } \\
\text { nualised net } \\
\text { return }\end{array}$ & $\begin{array}{l}\text { Average an- } \\
\text { nualised s.d. }\end{array}$ & Average size ${ }^{\mathrm{a}}$ \\
\hline \multirow{3}{*}{ Islamic } & Europe OE Islamic Equity & & 262 & $4.51 \%$ & $18.36 \%$ & $44,963,318.70$ \\
\hline & Middle East OE Equity & & 73 & $4.60 \%$ & $19.69 \%$ & $69,541,837.43$ \\
\hline & Total & & 335 & $4.53 \%$ & $18.65 \%$ & $49,002,445.90$ \\
\hline
\end{tabular}

a Size (assets) in USD. 
Table 4: Summary statistics for the benchmarks

\begin{tabular}{|c|c|c|c|}
\hline Type of fund & Factors & $\begin{array}{l}\text { Average annu- } \\
\text { alized net re- } \\
\text { turn }\end{array}$ & $\begin{array}{l}\text { Average annu- } \\
\text { alized s.d. }\end{array}$ \\
\hline \multirow{3}{*}{ Islamic } & FTSE World & $4.48 \%$ & $17.69 \%$ \\
\hline & DJ Islamic World & $3.11 \%$ & $18.21 \%$ \\
\hline & FTSE AW Middle East\&Africa & $13.49 \%$ & $23.46 \%$ \\
\hline
\end{tabular}


Table 5: Performance, Islamic funds

\begin{tabular}{|c|c|c|c|c|c|c|c|c|c|c|}
\hline \multirow[b]{2}{*}{ Type of fund } & \multirow[b]{2}{*}{ Morningstar category } & \multicolumn{5}{|c|}{ Percentage of total number of funds in group } & \multicolumn{4}{|c|}{ Annualized performance } \\
\hline & & $\begin{array}{l}\text { Number of } \\
\text { funds }\end{array}$ & $<0$ & $\begin{array}{l}p \text {-value } \\
\leq 0.05\end{array}$ & $>0$ & $\begin{array}{l}p \text {-value } \\
\geq 0.05\end{array}$ & $\begin{array}{c}\text { Mean (un- } \\
\text { weighted } \\
\text { average) }\end{array}$ & Median & $\begin{array}{l}\text { Weighted } \\
\text { average (by } \\
\text { fund size) }\end{array}$ & $\begin{array}{l}\text { Weighted } \\
\text { average (by } \\
\text { fund life) }\end{array}$ \\
\hline \multirow{3}{*}{ Islamic } & Europe OE Islamic Equity & 262 & $51.15 \%$ & $4.58 \%$ & $48.85 \%$ & $6.49 \%$ & $-0.27 \%$ & $-0.23 \%$ & $2.44 \%$ & $1.65 \%$ \\
\hline & Middle East OE Equity & 73 & $34.25 \%$ & $5.48 \%$ & $65.75 \%$ & $2.74 \%$ & $3.19 \%$ & $2.11 \%$ & $6.05 \%$ & $2.03 \%$ \\
\hline & All funds, Islamic & 335 & $47.46 \%$ & $4.78 \%$ & $52.54 \%$ & $5.67 \%$ & $0.49 \%$ & $0.35 \%$ & $3.28 \%$ & $1.76 \%$ \\
\hline
\end{tabular}


Table 6: Comparative performance of survivor vs. non-survivor funds, Islamic funds

\begin{tabular}{|c|c|c|c|c|c|c|}
\hline \multirow[t]{2}{*}{ Comparison } & \multicolumn{2}{|c|}{ All funds } & \multicolumn{2}{|c|}{$\begin{array}{c}\text { Europe OE Islamic } \\
\text { Equity }\end{array}$} & \multicolumn{2}{|c|}{$\begin{array}{l}\text { Middle East OE } \\
\text { Equity }\end{array}$} \\
\hline & Difference & $p$-value & Difference & $p$-value & Difference & $p$-value \\
\hline$S=27-S \geq 4$ & $1.31 \%$ & 0.293 & $0.63 \%$ & 0.366 & $2.12 \%$ & 0.363 \\
\hline$S<4-S \geq 4$ & $-3.85 \%$ & 0.022 & $-1.48 \%$ & 0.164 & - & - \\
\hline$N S \geq 4-\bar{S} \geq 4$ & $-6.54 \%$ & 0.000 & $-6.34 \%$ & 0.000 & $-2.33 \%$ & 0.347 \\
\hline$N S<4-S \geq 4$ & $-8.22 \%$ & 0.000 & $-11.23 \%$ & 0.000 & $0.97 \%$ & 0.420 \\
\hline
\end{tabular}

For interpretation of $S=27, S \geq 4, S<4, N S \geq 4$ and $N S<4$ see Table 2 
Table 7: Persistence analysis, Islamic funds, all

\begin{tabular}{|c|c|c|c|c|c|c|c|c|c|c|}
\hline \multicolumn{11}{|c|}{ PANEL A: Half-yearly } \\
\hline & \multicolumn{10}{|c|}{ Decile: } \\
\hline & $D_{1}$ & $D_{2}$ & $D_{3}$ & $D_{4}$ & $D_{5}$ & $D_{6}$ & $D_{7}$ & $D_{8}$ & $D_{9}$ & $D_{10}$ \\
\hline Annualized constant (\%) & -4.73 & -2.42 & -1.48 & 1.09 & 1.43 & 0.69 & 0.45 & 4.70 & 7.88 & 8.68 \\
\hline Standard $p$-value & 0.204 & 0.455 & 0.607 & 0.675 & 0.57 & 0.795 & 0.874 & 0.082 & 0.046 & 0.077 \\
\hline Cross-sectional $p$-value & 0.000 & 0.006 & 0.024 & 0.623 & 0.538 & 0.712 & 0.761 & 0.025 & 0.000 & 0.000 \\
\hline \multicolumn{11}{|c|}{ PANEL B: Yearly } \\
\hline & \multicolumn{10}{|c|}{ Decile: } \\
\hline & $D_{1}$ & $D_{2}$ & $D_{3}$ & $D_{4}$ & $D_{5}$ & $D_{6}$ & $D_{7}$ & $D_{8}$ & $D_{9}$ & $D_{10}$ \\
\hline Annualized constant (\%) & 1.96 & 0.47 & -1.16 & 1.29 & 3.04 & 1.45 & 4.95 & 5.39 & 5.29 & 9.25 \\
\hline Standard $p$-value & 0.628 & 0.869 & 0.668 & 0.652 & 0.209 & 0.556 & 0.083 & 0.069 & 0.125 & 0.084 \\
\hline Cross-sectional $p$-value & 0.746 & 0.931 & 0.009 & 0.850 & 0.525 & 0.827 & 0.170 & 0.121 & 0.130 & 0.001 \\
\hline
\end{tabular}


Table 8: Persistence analysis, Islamic funds, survivors ${ }^{\mathrm{a}}$

\begin{tabular}{|c|c|c|c|c|c|c|c|c|c|c|}
\hline \multicolumn{11}{|c|}{ PANEL A: Half-yearly } \\
\hline & \multicolumn{10}{|c|}{ Decile: } \\
\hline & $D_{1}$ & $D_{2}$ & $D_{3}$ & $D_{4}$ & $D_{5}$ & $D_{6}$ & $D_{7}$ & $D_{8}$ & $D_{9}$ & $D_{10}$ \\
\hline Annualized constant (\%) & -1.69 & -3.60 & 1.72 & 1.95 & 5.40 & 2.56 & 3.74 & 6.51 & 11.73 & 7.81 \\
\hline Standard $p$-value & 0.664 & 0.213 & 0.564 & 0.496 & 0.052 & 0.404 & 0.216 & 0.039 & 0.008 & 0.124 \\
\hline Cross-sectional $p$-value & 0.006 & 0.000 & 0.806 & 0.775 & 0.192 & 0.685 & 0.460 & 0.085 & 0.000 & 0.026 \\
\hline \multicolumn{11}{|c|}{ PANEL B: Yearly } \\
\hline & \multicolumn{10}{|c|}{ Decile: } \\
\hline & $D_{1}$ & $D_{2}$ & $D_{3}$ & $D_{4}$ & $D_{5}$ & $D_{6}$ & $D_{7}$ & $D_{8}$ & $D_{9}$ & $D_{10}$ \\
\hline Annualized constant (\%) & 2.44 & 6.58 & 6.02 & 0.76 & 2.61 & 5.54 & 5.63 & 6.50 & 7.83 & 9.40 \\
\hline Standard $p$-value & 0.549 & 0.044 & 0.057 & 0.769 & 0.347 & 0.063 & 0.057 & 0.045 & 0.042 & 0.103 \\
\hline Cross-sectional $p$-value & 0.872 & 0.266 & 0.350 & 0.964 & 0.859 & 0.430 & 0.413 & 0.280 & 0.127 & 0.040 \\
\hline
\end{tabular}

a Surviving funds at the end of the sample period, with data for at least 4 semesters (funds $S=27$ and $S \geq 4$ in Table 1). 
Figure 1: Performance persistence, Islamic funds

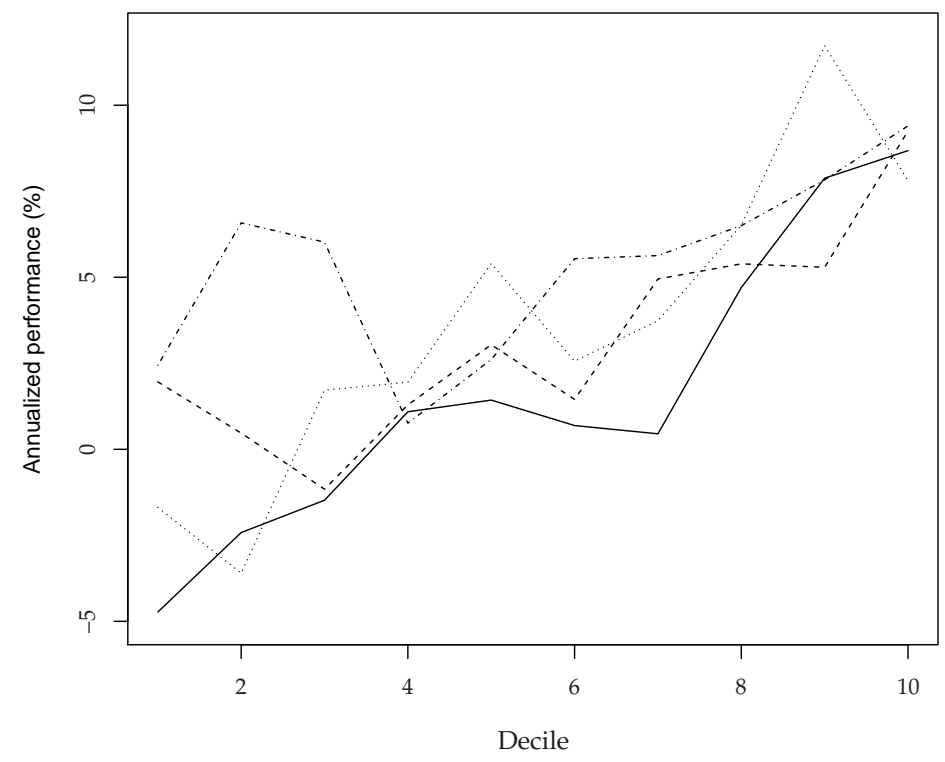

- All, half-yearly

All, yearly

…... $S=27 \& S>4$, half-yearly

…. $S=27 \& S>4$, yearly 